\title{
Quantitative and cytochemical studies of mast cell proteases in rat ovaries and uteri in various reproductive states
}

\author{
R. G. Gosden ${ }^{1}$, J. F. Huntley ${ }^{2}$, A. Douglas ${ }^{1}$, L. Inglis ${ }^{2}$ and \\ H. R. P. Miller ${ }^{2, *}$ \\ ${ }^{1}$ Department of Physiology, University Medical School, Edinburgh EH8 9AG, UK; and \\ ${ }^{2}$ Moredun Research Institute, 408 Gilmerton Road, Edinburgh EH17 7JH, UK
}

\begin{abstract}
A role for mast cell proteases (RMCP I and II) in the cyclical remodelling of ovarian and uterine tissues of rats was investigated in the oestrous and pregnancy cycles using immunocytochemistry and enzyme-linked immunosorbent assays. The concentrations of RMCP I exceeded that of RMCP II by 100-fold in both tissues, but were always much higher in uteri than ovaries. Most of the protease activity in the uterus was located in the myometrium, whereas it was more focally distributed in the hilus and medulla of the ovary. Protease activity was confined to mast cells identified by metachromatic staining and no single cell contained both proteases. The concentrations of RMCP I and II in the two organs did not fluctuate throughout the 4-day oestrous cycle. Neither were RMCP I concentrations in the uterus altered by administration of diethylstilboestrol to ovariectomized animals, although total amounts per uterus were substantially greater than in controls. Concentrations of RMCP I were substantially reduced in the uterus after day 6 of pregnancy and rose during the puerperium. The reduction was greater in pregnant than in pseudopregnant horns and tended to be lower in the vicinity of conceptuses than between them. The physiological significance of the lower mast cell protease concentrations is unclear, although their absence may contribute to the decreased protein catabolism during pregnancy.
\end{abstract}

\section{Introduction}

The role of mast cells in the female reproductive tract and ovary, in which they are widely distributed, has been the subject of investigation and speculation for several decades. The mast cell mediator, histamine, was first implicated in decidualization of the rodent uterus for implantation by Shelesnyak (1960), and later studies suggested that it had a role in ovulation (Kobayashi et al., 1983). Changes in numbers of mast cells occur in reproductive cycles and pregnancy (Iversen 1960; Brandon and Evans, 1983; Krishna et al., 1989; Gaytan et al, 1991) and mast cell degranulation coincides with the preovulatory surge of LH (Jones et al., 1980; Krishna and Terranova, 1985). The numbers of granulated mast cells and concentrations of histamine in the uterus fall at the time of implantation (Marcus et al., 1964; Brandon and Bibby, 1979) and a combination of $\mathrm{H}_{1}$ and $\mathrm{H}_{2}$ antagonists partially inhibit implantation in rats (Brandon and Wallis, 1977). The physiological significance of histamine in reproduction still remains unclear, however, and the issue is clouded further by the observation in $W$ mutant mice (deficient in both mast cells and oocytes) that pregnancies can be established (Loutit et al., 1982; Wordinger et al., 1985; Wordinger

${ }^{*}$ Present address: Department of Veterinary Clinical Studies, University of Edinburgh, Bush Estate, Roslin, Midlothian, UK.

Received 11 November 1992. et al., 1986). Much less attention has been paid to the possible roles of either mast cell heparin or monoamines than to histamine in reproduction (McKercher et al., 1973).

In view of the well-established presence of serine proteases in mast cells, representing as much as $30 \%$ of the total granule mass, it is surprising that their potential significance for fertility has been completely overlooked so far (Darzynkiewicz and Barnard, 1967). Two subsets of mast cells can be identified according to protease composition in rat tissues. Rat mast cell protease I (RMCP I), a highly cationic and insoluble enzyme, is mainly located in mast cells of connective tissue. In contrast, RMCP II, a highly soluble and less cationic protease, characterizes mast cells in mucosal tissues (Gibson and Miller, 1986; Gibson et al., 1987). These enzymes are chymases; collagen Type $\mathrm{IV}$ in basement membranes is one of their substrates (Sage et al., 1979) and another activity is the activation of procollagenases in fibroblasts (Birkedal-Hansen et al., 1976). There is, therefore, a basis for suspecting that these proteases contribute to remodelling the extracellular matrix of (1) the ovary as follicles and corpora lutea grow and regress or (2) the uterus during the oestrous cycle and pregnancy particularly during postpartum involution when the rate of collagen breakdown and collagenase activity are highest (Geyer ef al., 1977; Woessner, 1979). We have therefore investigated the distributions and concentrations of mast cell proteases in the female reproductive tract during the 4-day oestrous cycle, pregnancy and puerperium. 

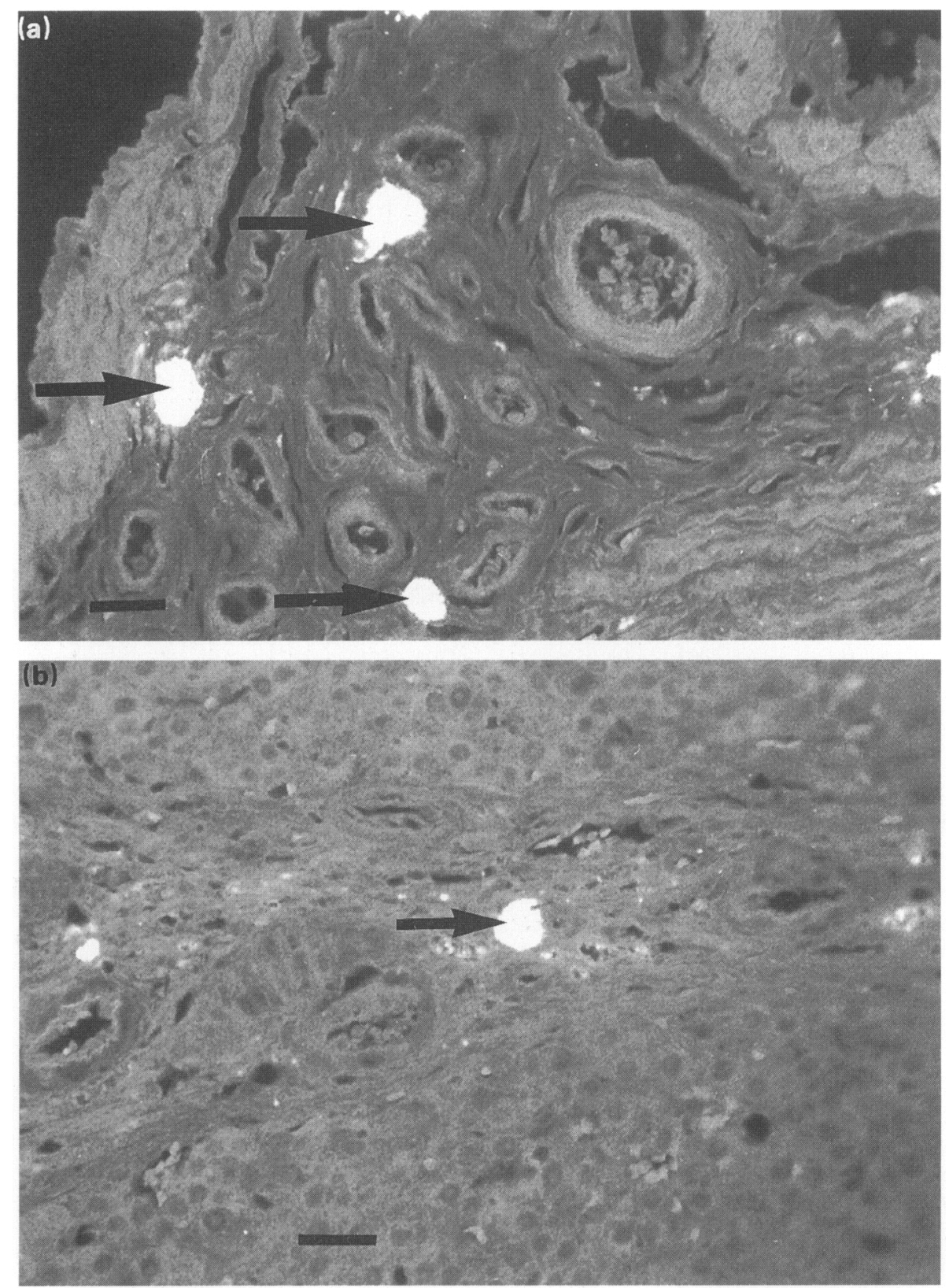

Fig. 1. (a) Section of uterus demonstrating the immunofluorescent localization of rat mast cell protease I (RMCP I) in mast cells within the rat myometrium (arrows). Sections were incubated with rabbit antibody to RMCP I followed by ovine anti-rabbit IgG-fluorescein isothiocyanate (FITC). (b) Section of ovary stained as above, showing RMCP I-containing mast cell within the medulla (arrow). (Bar $=40 \mu \mathrm{m})$.

\section{Materials and Methods}

\section{Preparation of tissue specimens}

The oestrous cycles of virgin Sprague-Dawley rats weighing approximately $200 \mathrm{~g}$ were monitored by vaginal lavage and staining with Giemsa. Six animals presenting two consecutive 4-day cycles were killed on each of the days of the cycle (prooestrus, oestrus, metoestrus, dioestrus), and their uteri and ovaries were dissected. Another group of 25 animals was mated with males of the same strain and autopsies were done between days 6 and 21 post-coitum (day $1=$ day of spermatozoa in vaginal smear). Seven nonpregnant controls were examined at the same time. The rats examined on days $6-8$, were given an i.v. injection of $1 \mathrm{ml} 1 \%(\mathrm{w} / \mathrm{v})$ Pontamine Sky Blue dye (Searle, High Wycombe) 15 min before death to locate early implantation sites (Psychoyos, 1960). One of each pair of Fallopian tubes in 13 animals was ligated under sodium pentobarbitone anaesthesia $\left(35 \mathrm{mg} \mathrm{kg}^{-1}\right.$ i.p.) two weeks before mating to establish pseudopregnancy conditions in one uterine horn with a pregnancy on the contralateral side. An additional group of eight rats was examined on the second day post-partum. 

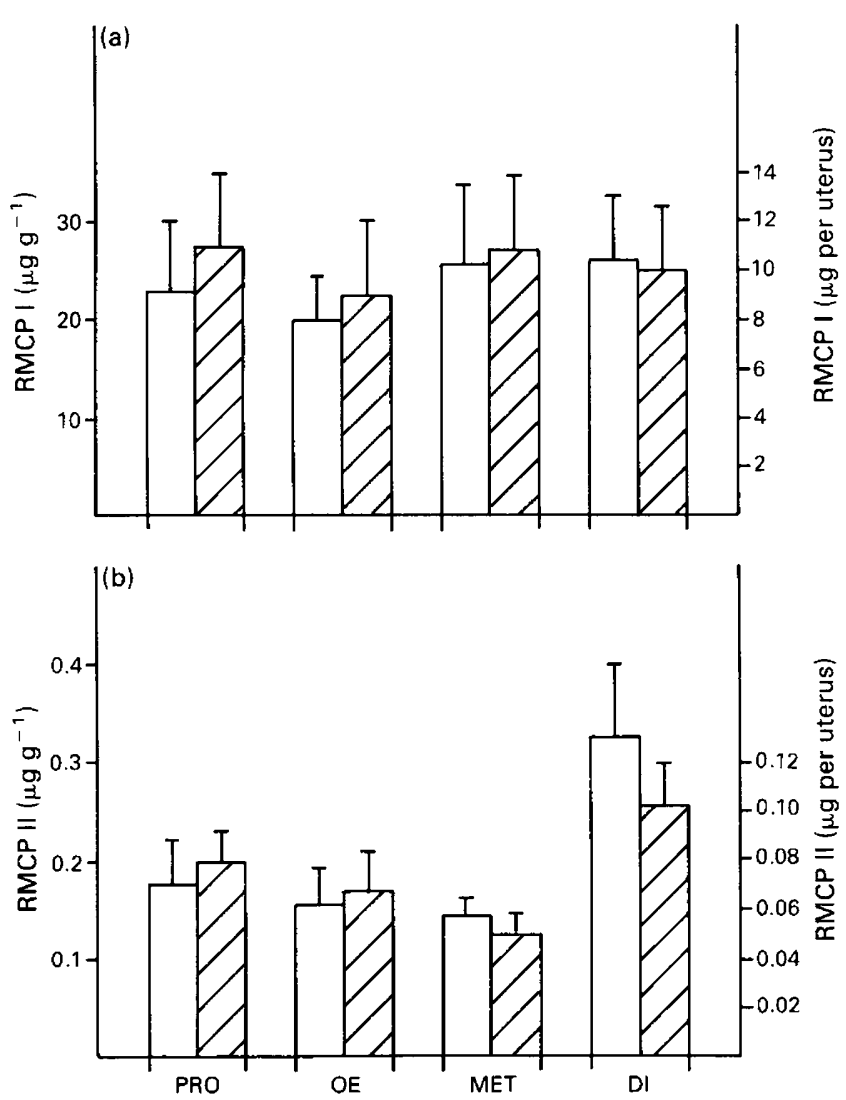

Fig. 2. Variations in amounts of rat mast cell protease (RMCP), (a) RMCP I and (b) RMCP II, in the uterus during the 4-day oestrous cycle. PRO: pro-oestrus; $\mathrm{OE}$ : oestrus; $\mathrm{MET}$ : metoestrus and DI: dioestrus. The results are expressed as means \pm SEM of RMCP per unit wet weight of tissue $\square$ and per uterus $\square$.

A further group of 16 rats was ovariectomized under the same anaesthetic and treated daily on the fourth to seventh post-operative days, inclusive, with either $1 \mu \mathrm{g}$ or $10 \mu \mathrm{g}$ diethylstilboestrol $\mathrm{kg}^{-1}(\mathrm{DES})$ or arachis oil $(0.2 \mathrm{ml})$ s.c. These rats were killed on the following day.

The animals were killed by cervical dislocation and the ovaries and uterine horns were dissected and blotted to remove surface blood and uterine luminal fluid. For the gravid horns, two implants and intervening uterine segments were prepared from each animal. The tissues were weighed and homogenized with a Polytron homogenizer (Northern Media Supply Ltd, North Cave, UK) at dilutions of either $1: 5$ or $1: 20(\mathrm{w}: \mathrm{v})$ in Tris-HCl buffer $\left(20 \mathrm{mmol}^{-1}, \mathrm{pH} 7.5\right)$ containing $1.5 \mathrm{~mol}$ $\mathrm{NaCl} l^{-1}$ and stored at $-20^{\circ} \mathrm{C}$. Additional pieces of ovarian and uterine tissue were fixed in $4 \%$ paraformaldehyde ( $\mathrm{pH} 7.4$ ) overnight and prepared as $6 \mu \mathrm{m}$ paraffin wax sections on gelatin-subbed slides for immunocytochemistry.

\section{Immunocytochemistry}

The locations of RMCP I and RMCP II in tissues were determined by the paired immunofluorescence technique described by Huntley et al. (1990). Briefly, tissue sections were pretreated with 3-amino-9-ethyl-carbazole to block nonspecific
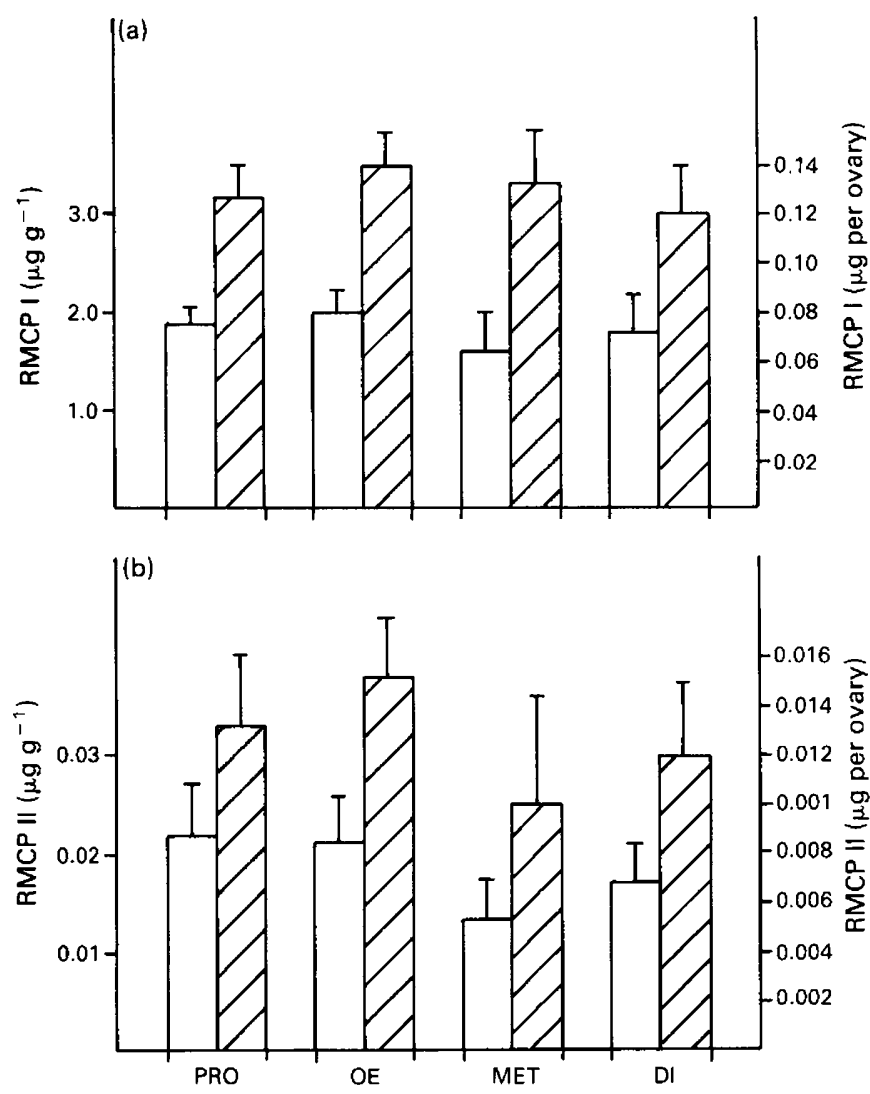

Fig. 3. Variations in amounts of rat mast cell protease (RMCP), (a) RMCP I and (b) RMCP II, in the ovary during the 4-day oestrous cycle. PRO: pro-oestrus; OE: oestrus; MET: metoestrus and DI: dioestrus. The results are expressed as means \pm SEM of RMCP per unit wet weight of tissue $\square$ and per ovary $\oslash$.

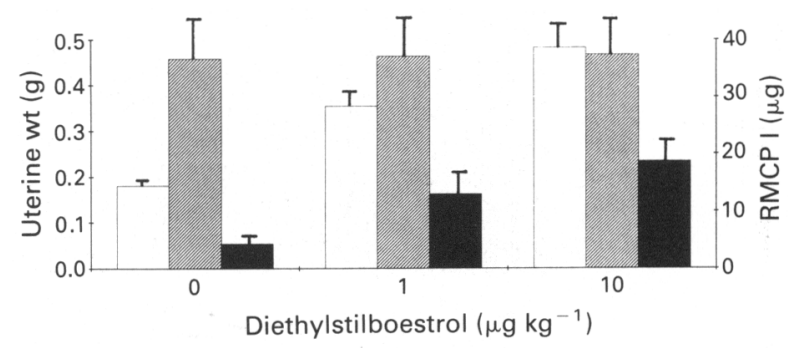

Fig. 4. The effects of administering diethylstilboestrol to ovariectomized rats on $\square$ uterine weight, $₫$ RMCP I expressed in $\mu \mathrm{g} \mathrm{g}^{-1}$ uterus, and $\square \mathrm{RMCP} I$ in $\mu \mathrm{g}$ per whole organ. The means and SEMs are given.

fluorescence in eosinophils and then incubated sequentially with rabbit $\mathrm{F}\left(\mathrm{ab}^{\prime}\right)_{2}$ anti-RMCP I $\left.(10 \mu \mathrm{g} \mathrm{ml})^{-1}\right)$, ovine antirabbit IgG-methylrhodamine isothiocyanate (TRITC) $(1 / 50)$ (Cooper Biochemicals, Philadelphia), monoclonal anti-RMCP II $\left(10 \mu \mathrm{g} \mathrm{m}^{-1}\right)$ and ovine anti-mouse IgG-fluorescein isothiocyanate (FITC) (1/100) (Binding Site Ltd, Birmingham). All antibodies were diluted in $10 \%$ ovalbumin PBS, and slides were washed six times in PBS between incubation with each reagent. High background autofluorescence of granules in macrophages observed with green light (TRITC) excitation was 


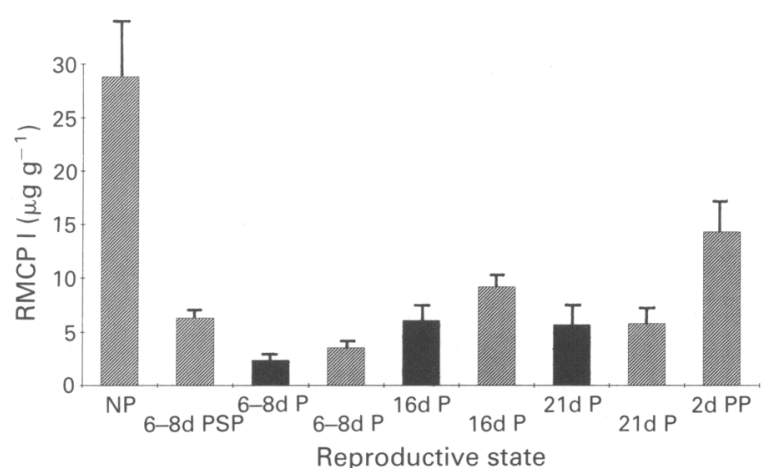

Fig. 5. Effects of different reproductive states on mean \pm SEM concentration of RMCP I in the rat uterus. Concentrations in pregnant uteri (P) were much lower than in nonpregnant $(\mathrm{NP})(P<0.01)$ and postparturient horns (PP) $(P=0.05)$, whereas those in pseudopregnant horns (PSP) were significantly higher than in corresponding pregnant horns $(P<0.05)$. The pregnancy values for days $6-8(6-8 \mathrm{~d})$ and 16 (d16) were lower in uterine tissue immediately adjacent to conceptuses (ם) than in intervening segments $(\mathbb{Z})$.

reduced considerably, although not eliminated, by immersing slides in chloroform for $30 \mathrm{~min}$. The mast cell identity of fluorescing cells was confirmed by additional sections reacting with rabbit anti-RMCP I followed by goat anti-rabbit-FITC (Sera-Lab Ltd, Crawley Down). Further sections were also stained with $0.5 \%$ toluidine blue ( $\mathrm{pH} 4.5)$ to compare the tissue distribution of granulated mast cells (Enerback, 1966).

\section{Quantitation of mast cell proteases}

The amounts of RMCP I and II in tissue extracts were measured by an enzyme-linked immunosorbent assay (ELISA) technique (Huntley et al., 1990). Dynatech M129B plates (Dynatech Laboratories Ltd, Billingshurst) were coated with either an affinity-purified polyclonal sheep antibody to RMCP I or a murine monoclonal antibody to RMCP II. After incubating at room temperature with known concentrations of standard protease preparations or different dilutions of the test sample, a second antibody was added. In the first case, this was rabbit anti-RMCP I and, in the second, ovine anti-RMCP II labelled with horseradish peroxidase according to the method of Nakane and Kawaoi (1974). A third antibody was added for detecting RMCP I, namely, goat anti-rabbit IgG conjugated to horseradish peroxidase (Sera-Lab). The peroxidase activity of the conjugates was estimated after they were reacted with orthophenylene diamine $\left(400 \mathrm{mg} \mathrm{l^{-1 }}\right)$ in $0.1 \mathrm{~mol}$ citratephosphate buffer $\mathrm{l}^{-1}$ (pH 5.0) containing $0.4 \mathrm{mg}$ hydrogen peroxide $1^{-1}$ (Sigma, London). The reactions were halted by addition of $2.5 \mathrm{~mol} \mathrm{H}_{2} \mathrm{SO}_{4} \mathrm{I}^{-1}$ and the coloured products were measured using a Titertek Multiscan plate reader (Flow Laboratories, Irvine). Concentrations were compared by ANOVA, Duncan's multiple range test and the paired $t$ test.

\section{Results}

\section{Tissue distribution of mast cell proteases}

Intense red (TRITC) fluorescence for RMCP I was observed in cells of the uterine serosa, mesometrium and myometrium.
These fluorescent cells were generally large ( $>15 \mu \mathrm{m}$ diameter), granular in appearance and had a scattered distribution corresponding to toluidine blue-stained mast cells in comparable sections. The density of RMCP I-containing cells in the ovary was lower, but they too had a similar distribution to metachromatically stained cells. Most were observed in the hilus, close to the larger ovarian blood vessels or in the medulla; few were found in the cortex. Despite the persistence of some autofluorescence after quenching sections in chloroform, RMCP I fluorescence could be localized unequivocally in mast cells with the antibody-FITC conjugate (Fig. Ia, b).

Few mast cells containing RMCP II were observed in either tissue, a finding which is in accord with the much lower tissue concentrations of RMCP II compared with those for RMCP I (see next section). Few FITC-positive cells were noted in the uterine mucosa, although these fluoresced weakly. Cells exhibiting dual fluorescence for RMCP I and II were not observed in these tissues.

\section{Concentrations of proteases in different reproductive states}

Protease concentrations in the ovary and uterus during the oestrous cycle are shown (Figs 2 and 3) which indicate that amounts of RMCP I in both organs exceeded those of RMCP II by 100 -fold. The nonpregnant rat uterus contained approximately $10 \mu \mathrm{g}$ of RMCP I in toto, corresponding to a concentration of $20-40 \mu \mathrm{g} \mathrm{g}^{-1}$ (Fig. 2). By contrast, the ovary contained $0.1-0.2 \mu \mathrm{g}$ of RMCP I and only a trace of RMCP II $(0.001 \mu \mathrm{g})$ (Fig. 3). Individual organs contained widely variable amounts of protease, but there was no evidence of significant variation according to the stage of the cycle in either organ whether expressed as a total amount or concentration per unit organ weight $(P>0.05)$.

Oestrogen treatment of ovariectomized rats produced the expected dose-dependent uterotrophic response $(P<0.01)$ (Fig. 4). The amounts of RMCP I per uterus rose with dose and at the same rate with uterine weight $(P<0.05)$, whereas protease concentrations in the two treatment groups remained the same as those in controls. The amounts of RMCP II in this experiment and in the pregnancy study followed a similar pattern; they are not recorded here because only trace amounts were present.

Concentrations of RMCP I in the uterus were strikingly lower in pregnancy than in virgin animals $(P<0.01)$ or during the puerperium $(P=0.05)$ (Fig. 5). Concentrations fell abruptly to approximately $20 \%$ of the nonpregnant values by days $6-8$ of pregnancy (data combined, as there was no difference between these days). RMCP I concentrations appeared to be higher at 16 days of gestation than at earlier stages of pregnancy $(P<0.01)$, although they failed to reach statistical significance when compared with pseudopregnancy or day 21 $(P>0.05)$. By the second day post partum RMCP I concentrations had risen appreciably, although they had not reached nonpregnant values $(P<0.01)$.

Concentrations of RMCP I in pseudopregnant uterine horns on days 6-8 were lower than those in nonpregnant controls $(P<0.01)$, but they were significantly higher than the contralateral pregnant horn $(P<0.05$, Fig. 5). An additional source of variation was the location of specimens taken from pregnant horns. Amounts of protease were significantly lower in the 
vicinity of conceptuses than between conceptuses on days 6-8 $(P<0.005)$ and $16(P=0.05)$, although not at later stages of pregnancy.

\section{Discussion}

Methods for localizing and measuring the two mast cell proteases, RMCP I and II, in rats provide accurate and sensitive monitors of the rat mast cell subpopulations in tissues and organs during physiological and pathological processes (Woodbury et al., 1984; Gibson and Miller, 1986). The present results demonstrate that the major mast cell protease in the rat ovary and uterus is that which normally characterizes connective tissues, namely, RMCP I (Gibson et al., 1987), and the concentrations in the uterus exceeded that in the ovary by about two orders of magnitude.

Tissue concentrations of mast cell proteases are assumed to reflect mainly the amounts of enzyme stored in granules rather than in blood or tissue fluids which contain relatively low concentrations of RMCP I and II (Cummins et al., 1988; J. Huntley, unpublished observations). A physiological role might be inferred if concentrations fell abruptly as a result of degranulation at a particular stage of a reproductive cycle. The absence of significant changes in concentrations or total amounts of either protease during the oestrous cycle suggests, however, that, although they may be acting tonically on the extracellular matrix, they are not responding to hormonal signals and are unlikely therefore to be important components of the mechanism for cyclical remodelling of the ovary and uterus. The substantial variations in concentrations at all stages of the cycle suggest that analysis of mast cell subpopulations may be more rewarding.

The oestrous cycle of Sprague-Dawley rats, normally of only 4 days duration, may be too short for effects of low concentrations of ovarian hormones on long-lived tissue mast cells and their mediators to become apparent. When variations in the density of metachromatically-staining cells in the uterus have been found they have been modest (Gibbons and Chang, 1972). However, even when pharmacological doses of a synthetic oestrogen, diethylstilboestrol, were given for four consecutive days the marked uterotrophic responses were not accompanied by effects on RMCP I concentrations. The total amounts of protease were, however, increased at the same rate as tissue wet weight, suggesting that mast cells are being regulated according to tissue mass. Presumably, new mast cells had formed by mitosis of existing cells or by migration and differentiation of stem cells, because there was no immunocytochemical evidence of degranulation. Since RMCPs are thought to be released with histamine, this evidence appears to conflict with studies showing that oestrogen induces degranulation, although the actions of this hormone on mast cells are evidently neither direct nor straightforward (Cocchiara et al., 1992).

If mast cell proteases were involved in remodelling the uterus during the puerperium, it is plausible, in light of evidence of oestrogen-induced degranulation at implantation (Marcus et al., 1964), that the postpartum oestrus may trigger their release. The present results do not support this hypothesis, however, as might be anticipated from the aforementioned studies of the oestrous cycle. Rather than decreasing after birth (suggesting degranulation), concentrations of RMCP I actually rose, confirming that mast cells return to the cell population density of nompregnancy (Shimizu and Hokano, 1987).

The low concentrations of RMCP I throughout pregnancy were the most striking findings of the whole study and confirm histological evidence that mast cell numbers decline (Hore and Mehrotra, 1988). This change occurred by day 6 and was maintained until the day before birth (day 21) despite a slight upturn at day 16 of pregnancy. This increase appeared to be due to a combination of systemic and local factors. Concentrations of protease in pseudopregnant uterine horns were also substantially lower than in nonpregnant uteri, although it remains unclear whether an ovarian hormone is responsible. On the other hand, they were substantially higher than those of contralateral pregnant horns. There were, furthermore, local variations. The concentrations were lower in the vicinity of conceptuses than between them, suggesting that mechanisms regulating mast cell density in the uterus had been locally suppressed, at least during the early phase after implantation. The absence of mast cells in decidual tissue may be sufficient to explain this difference $U$. Brandon, personal communication). Considerable remodelling of connective tissues occurs in the early implantation chamber (Clark et al., 1992), but it is unlikely that the RMCPs make an important contribution to this adaptive process as they remain low in this site throughout pregnancy. On the contrary, the lower activities throughout pregnancy may be contributing to the general lowering of protein breakdown and proteolytic enzymes which is essential for uterine growth to occur (Morton and Goldspink, 1986).

We thank J. Brandon for advice and improvements to the manuscript. Part of this work was carried out during the tenure of a project grant from The Wellcome Trust to R. G. Gosden, and the support of the Scottish Office Agriculture and Fisheries Department is also gratefully acknowledged.

\section{References}

Birkedal-Hansen H, Cobb CM, Taylor RE and Fullmer HM (1976) Activation of fibroblast procollagenase by mast cell proteases Biochimica et Biophysica Acta 438 273-286

Brandon JM and Bibby MC (1979) A study of changes in uterine mast cells during early pregnancy in the rat Biology of Reproduction 20 977-980

Brandon JM and Evans JE (1983) Changes in uterine mast cells during the estrous cycle in the Syrian hamster American Joumal of Anatomy 167 241-247

Brandon JM and Wallis RM (1977) Effect of mepyramine, a histamine $\mathrm{H}_{1^{-}}$, and burimamide, a histamine $\mathrm{H}_{2}$-receptor antagonist, on ovum implantation in the rat Journal of Reproduction and Fertility 50 251-254

Clark DE, Hurst PR, Myers DB and Spears GF (1992) Collagen concentrations in dissected tissue compartments of rat uterus on Days 6,7 and 8 of pregnancy Journal of Reproduction and Fertility 94 169-175

Cocchiara R., Albeggiani G., di Trapani G., Azzolina A., Lampiasi N., Rizzo F., Diotallevi L., Gianaroli L. and Geraci D (1992) Oestradiol enhances in vitro the histamine release induced by embryonic histamine releasing factor (EHRF) from uterine mast cells Human Reproduction 7 1036-1041

Cummins AG, Steele TW, Labrooy JT and Shearman DJC (1988) Maturation of the rat small intestine at weaning: changes in epithelial cell kinetics, bacterial flora and mucosa immune activity Gut $291672-1679$

Darzynkiewicz Z and Barnard EA (1967) Specific proteases of the rat mast cell Nature $2131198-1202$

Enerback L (1966) Mast cells in rat gastrointestinal mucosa. II. Dye binding and metachromatic properties Acta Pathologica et Microbiologica Scandinavica 66 $303-312$ 
Gaytan F, Aceitero J, Bellido C, Sanchez-Criado JE and Aguilar E (1991) Estrous cycle-related changes in mast cell numbers in several ovarian compartments in the rat Biology of Reproduction 45 27-33

Geyer H, Muller U and Afting E-G (1977) Enzyme activities in different cell compartments of the involuting rat myometrium European Journal of Biochemistry $79483-490$

Gibbons AF and Chang MC (1972) Number of mast cells in the rat uterus with special reference to hormonal treatment and decidual response Biology of Reproduction 6 193-203

Gibson S and Miller HRP (1986) Mast cell subsets in the rat distinguished immunohistochemically by their content of serine proteinases Immunology $\mathbf{5 8}$ 101-104

Gibson S, Mackeller A, Newlands GFJ and Miller HRP (1987) Phenotypic expression of mast cell granule proteinases. Distribution of mast cell proteinases I and II in the rat digestive system Immunology $62621-627$

Hore A and Mehrotra PN (1988) Presence of a blastocyst and mast cell depletion of the mouse uterus Acta Anatomica 132 6-8

Huntley JF, Mackellar A, Newlands GFJ, Irvine J and Miller HRP (1990) Mapping of the rat mast cell granule proteinases RMCP I and II by enzyme linked immunosorbent assay and paired immunofluorescence APMIS 98 933-944

Iversen $\mathrm{OH}(1960)$ Mast cells in the myometrium of the human cervix uteri, and changes caused by androgenic and estrogenic hormones Acta Pathologica et Microbiologica Scandinavica 49 337-343

Jones RE, Duvall D and Guillette Jr, LJ (1980) Rat ovarian mast cells: distribution and cyclic changes Anatomical Record 197 489-493

Kobayashi Y, Wright KH, Santulli R, Kitai H and Wallach EE (1983) Effect of histamine blockers on the ovulatory process in the in vitro perfused rabbit ovary Biology of Reproduction 28 385-392

Krishna A and Terranova PF (1985) Alterations in mast cell degranulation and ovarian histamine in the proestrous hamster Biology of Reproduction 32 1211-1217

Krishna A, Beesley K and Terranova PF (1989) Histamine, mast cells and ovarian function Journal of Endocrinology 120 363-371
Loutit JF, Corp MJ and Adams PJV (1982) Radiosensitivity of mice with mutation at loci W,Ph. International joumal of Radiation Biology 42 93-97

Marcus GJ, Shelesnyak MC and Kraicer PF (1964) Studies on the mechanism of nidation: X Acta Endocrinologica 47 255-264

McKercher TC, van Orden III LS, Bhatnagar RK and Burke JP (1973) Estrogeninduced biogenic amine reduction in rat uterus Joumal of Pharmacology and Experimental Therapeutics 185 514-522

Morton AJ and Goldspink DF (1986) Changes in protein turnover in rat uterus during pregnancy American Journal of Physiology 250 E114-E120

Nakane PK and Kawaoi AJ (1974) Peroxidase-labelled antibody. A new method of conjugation Joumal of Histochemistry and Cytochemistry 22 1084-1091

Psychoyos A (1960) La réaction deciduale est precedée de modifications precosés de la permeabilité capillare de l'uterus Comptes rendus des Séances de la Société de Biologie 154 1384-1387

Sage H, Woodbury RG and Bornstein P (1979) Structural studies of human Type IV collagen Journal of Biological Chemistry 254 9893-9900

Shelesnyak MC (1960) Nidation of the fertilized ovum Endeavour 19 81-86

Shimizu K and Hokano M (1987) Collagen concentration and mast cells in perinatal murine uterus Acta Anatomica 129 262-264

Woessner Jr JF (1979) Total, latent and active collagenase during the course of post-partum involution of the rat uterus: effect of oestradiol Biochernical Joumal 180 95-102

Woodbury RG, Miller HRP, Huntley JF, Newlands GFJ, Palliser AC and Wakelin D (1984) Mucosal mast cells are functionally active during spontaneous expulsion of intestinal nematode infections in rat Nature $\mathbf{3 1 2}$ 450-452

Wordinger RJ, Orr EL, Pace K, Oakford L and Morrill A (1985) An assessment of mast cell deficient mice ( $W / W^{*}$ ) as a model sytem to study the role of histamine in implantation and deciduoma formation Joumal of Reproduction and Fertility 73 451-456

Wordinger RJ, Jackson FL and Morrill A (1986) Implantation, deciduoma formation and live births in mast cell deficient mice $\left(W / W^{v}\right)$ journal of Reproduction and Fertility 77 471-476 